\title{
Rainfall intensity-duration conditions for mass movements in Taiwan
}

\author{
Chi-Wen Chen ${ }^{1 *}$, Hitoshi Saito ${ }^{2,3}$ and Takashi Oguchi ${ }^{1,3}$
}

\begin{abstract}
Mass movements caused by rainfall events in Taiwan are analyzed during a 7-year period from 2006 to 2012. Data from the Taiwan Soil and Water Conservation Bureau reports were compiled for 263 mass movement events, including 156 landslides, 91 debris flows, and 16 events with both landslides and debris flows. Rainfall totals for each site location were obtained from interpolated rain gauge data. The rainfall intensity-duration $(I-D)$ relationship was examined to establish a rainfall threshold for mass movements using random sampling: $I=18.10( \pm 2.67) D^{-0.17( \pm 0.04)}$, where $/$ is mean rainfall intensity $(\mathrm{mm} / \mathrm{h})$ and $D$ is the time $(\mathrm{h})$ between the beginning of a rainfall event and the resulting mass movement. Significant differences were found between rainfall intensities and thresholds for landslides and debris flows. For short-duration rainfall events, higher mean rainfall intensities were required to trigger debris flows. In contrast, for long-duration rainfall events, similar mean rainfall intensities triggered both landslides and debris flows. Mean rainfall intensity was rescaled by mean annual precipitation (MAP) to define a new threshold: $I_{\text {MAP }}=0.0060( \pm 0.0009) D^{-0.17( \pm 0.04)}$, where $I_{\text {MAP }}$ is rescaled rainfall intensity and MAP is the minimum for mountainous areas in Taiwan (3000 mm). Although the I-D threshold for Taiwan is high, the $I_{\text {MAP }}-D$ threshold for Taiwan tends to be low relative to other areas around the world. Our results indicate that Taiwan is highly prone to rainfall-induced mass movements. This study also shows that most mass movements occur in high rainfall-intensity periods, but some events occur before or after the rainfall peak. Both antecedent and peak rainfall play important roles in triggering landslides, whereas debris flow occurrence is more related to peak rainfall than antecedent rainfall.
\end{abstract}

Keywords: Mass movements; Landslides; Debris flows; I-D thresholds; Rainfall; Typhoons

\section{Background}

Mass movements such as landslides and debris flows are common natural hazards in mountainous areas (Aleotti and Chowdhury 1999; Guzzetti et al. 1999; Dai et al. 2002; Dou et al. 2014). These hazards not only cause considerable loss of property and life but also ecological and environmental problems such as increased soil erosion and sediment discharge (Hovius et al. 1997; Claessens et al. 2007). Mass movements, especially shallow landslides and debris flows, are often triggered by heavy rainfall. Therefore, many studies have investigated rainfall thresholds for the initiation of mass movements across the globe using both physical and empirical models. Although the simplicity of the empirical approach neglects important hydrological controls, it offers a straightforward means for

\footnotetext{
*Correspondence: kevin4919@gmail.com

'Department of Natural Environmental Studies, Graduate School of Frontier Science, The University of Tokyo, 5-1-5 Kashiwanoha, Kashiwa Chiba 277-8568, Japan

Full list of author information is available at the end of the article
}

issuing regional-scale mass movement warnings based solely on rainfall data.

In order to derive empirical critical thresholds for mass movements, many mass movement studies have focused on rainfall parameters such as rainfall intensity, duration, cumulative rainfall, and antecedent rainfall (see Guzzetti et al. 2007, 2008 for detailed reviews). Among these, the relationship between rainfall intensity $(I)$ and duration $(D)$ is most commonly used to estimate rainfall thresholds (e.g., Caine 1980; Guzzetti et al. 2007, 2008; Brunetti et al. 2010; Saito et al. 2010a, 2014). Several studies have also found that peak rainfall intensity and the initiation of mass movements are often concurrent (Aleotti 2004; Chien-Yuan et al. 2005; Guzzetti et al. 2007, 2008; Dahal and Hasegawa 2008; Saito et al. 2010a, 2010b). Although antecedent rainfall also plays an important role in the initiation of mass movement (Kim et al. 1992; Glade 1997; Crozier 1999; Glade et al. 2000; Guzzetti et al. 2007, 2008; Dahal and Hasegawa $2008)$, intensity-duration $(I-D)$ thresholds and/or the peak

\section{实}


rainfall intensity are often used to predict mass movements and warn the appropriate authorities of potential mass movement hazards (Onodera et al. 1974; Keefer et al. 1987; Aleotti 2004; Hong et al. 2005; Cannon et al. 2008; Coe et al. 2008; Dahal and Hasegawa 2008; Guzzetti et al. 2008).

Taiwan is extremely susceptible to mass movements because of steep mountainous topography and frequent heavy rainfall and earthquakes. Thus, many studies have focused on understanding the underlying triggers of mass movements in Taiwan. For example, Chang and Chiang (2009) combined slope stability and statistical models to establish a landslide probability model based on geographical and hydrological data for landslides triggered by typhoon events. Lin and Chen (2012) used a rainfall kinetic energy conversion formula and rainfall intensity data from typhoon events between 1994 and 2008 to determine the landslide rainfall threshold for mountainous areas in central Taiwan $\left(2000 \mathrm{~J} / \mathrm{m}^{2}\right)$. They then used rainfall, sediment discharge, and flow discharge data from another typhoon event to validate this threshold as a predictor of landslides and resultant sediment discharge. In addition, Jan and Chen (2005) examined the $I-D$ thresholds of debris flows before and after the 1999 Chi-Chi earthquake for the Chenyoulan River catchment in central Taiwan. They used the debris flows caused by Typhoon Herb in 1996 for the $I-D$ threshold before the Chi-Chi earthquake and the debris flows caused by Typhoon Toraji and Nari in 2001 for the $I-D$ threshold after the Chi-Chi earthquake. They found that the $I-D$ threshold decreased after the Chi-Chi earthquake.

Although Taiwanese mass movement events have been widely investigated, studies have typically examined specific events or locations. Surprisingly, few studies have explored rainfall conditions associated with mass movements in Taiwan as a whole. Although Chien-Yuan et al. (2005) investigated the $I-D$ threshold of debris flows in Taiwan, their data were generally sourced from specific areas in northern and central Taiwan and only spanned the time period from 1989 to 2001, thus excluding more recent data. Since mass movements are densely distributed throughout Taiwan, it is important to develop a general relationship between the initiation of mass movements and rainfall conditions. Therefore, the objectives of this study are to analyze the mean intensity, peak intensity, and duration of rainfall associated with mass movements across Taiwan and to establish the $I-D$ threshold using recent data.

\section{Study area}

Taiwan is located on a convergent plate boundary between the Eurasian Continental and the Philippine Sea plates, with the Philippine Sea plate moving towards the Eurasian Continental plate at a rate of $80 \mathrm{~mm} /$ year (Yu et al. 1997). The subduction of the Philippine Sea plate beneath the
Eurasian Continental plate has resulted in the formation of an active mountain belt with over 200 peaks higher than $3000 \mathrm{~m}$ a.s.l. (Ho 1986; Teng 1990) and is responsible for frequent large earthquakes and an orogenic uplift rate of about 5-7 mm/year (Li 1976; Willett et al. 2003). The geological map provided by the Central Geological Survey of Taiwan (Ho 1988) illustrates the seven major geological zones of Taiwan (Fig. 1). Tertiary marine sedimentary rocks mainly underlie the western region and part of the northeastern coastal region. Central Taiwan is composed of metamorphic rocks. The pre-Tertiary metamorphic complex is exposed mainly in the eastern Central Range, while the majority of the western Central Range consists of Tertiary indurated metamorphosed argillaceous sedimentary rocks (Ho 1988). The eastern coastal region is underlain by volcanic-arc sediments, orogenic sediments, and a subduction-collision complex formed in the Pliocene to Pleistocene. Northern Taiwan consists mainly of agglomerates-masses of igneous rock fragments, and, finally, lowlands such as alluvial fans are mostly composed of Quaternary sediments.

Taiwan is located between $120^{\circ} \mathrm{E}$ and $122^{\circ} \mathrm{E}$ and between $22^{\circ} \mathrm{N}$ and $25^{\circ} \mathrm{N}$. According to the elevation histogram derived from a $10 \mathrm{~m}$ digital terrain model of Taiwan, about $68 \%$ of the country lies below $1000 \mathrm{~m}$ above sea level. The slope of mountainous areas is mostly between $30^{\circ}$ and $50^{\circ}$ (Fig. 1). Taiwan experiences tropical and subtropical-monsoon climates, with the boundary between the two climate regimes located in southern Taiwan (Wang and Ho 2002). The average temperature over the Taiwanese lowlands during the wet season (May-October) is above $20^{\circ} \mathrm{C}$, while the average temperature during the dry season (November-April) is between 14 and $20{ }^{\circ} \mathrm{C}$. In the mountain regions of central and southern Taiwan, the average temperature is lower than in other regions of the country.

On average, four typhoons strike Taiwan every year (Wu and Kuo 1999), causing heavy and concentrated rainfall. Average annual rainfall over Taiwan is $2500 \mathrm{~mm}$, but annual rainfall in mountainous regions can surpass $3000 \mathrm{~mm}$ (Shieh 2000). Approximately $60-80 \%$ of rainfall falls during the wet season (Fig. 2). Heavy rainfall and the steep topography of Taiwan have contributed to an erosion rate of 3-7 mm/year (Dadson et al. 2003). Landslides and debris flows represent the primary mechanisms for this erosion and are important for maintaining a balance between erosion and uplift (Dadson et al. 2003).

Taiwan is characterized by a fragile geological environment, and areas that display a high density of geological discontinuity are more prone to mass movements (Chen et al. 1999; Chen and Su 2001; Chuang et al. 2009). Interestingly, the number and magnitude of rainfall-induced mass movements increased after the 1999 Chi-Chi earthquake because slopes became more vulnerable (Chang and Slaymaker 


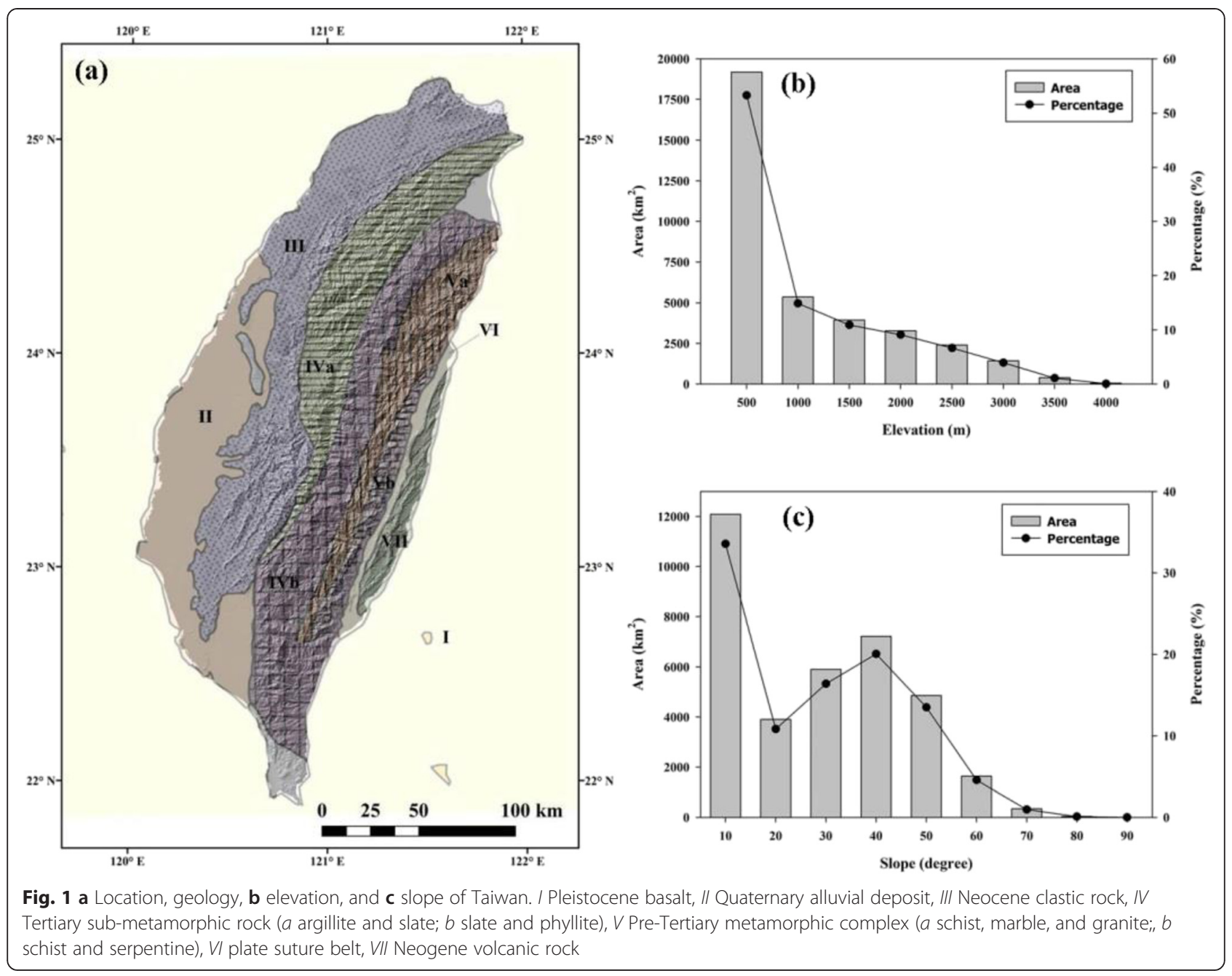

2002; Dadson et al. 2004; Cheng et al. 2005), which reduced both the maximum rainfall intensity and critical cumulative rainfall required to trigger mass movements (Lin et al. 2003; Chang et al. 2009; Shieh et al. 2009; Chen 2011).

\section{Methods}

\section{Mass movement data}

A total of 263 mass movements caused by rainfall events were analyzed during the 7-year period from 2006 to 2012 (Fig. 3). Mass movement data were compiled from the Soil and Water Conservation Bureau (SWCB) of Taiwan reports for 156 landslides, 91 debris flows, and 16 events with both landslides and debris flows (http://117.56.222.245/disasterInfo/ImpDisasterReport.aspx). The 16 events that included both types of mass movement were initiated as landslides, but these were subsequently completely or partially mobilized to form debris flows during the same rainfall event. Over the study period, mass movements across Taiwan occurred only during the wet season, with 1 in May, 26 in June, 33 in July, 141 in August, 24 in September, and 38 in October (Fig. 3).
To prevent secondary disasters and enable quick recovery, SWCB has conducted detailed field surveys after rainfall-induced mass movements that cause damage to houses and roads. The resultant reports contain information on the type, location, and approximate time (to the closest hour) of each event. The time of the event is estimated from real-time videos taken at observation stations, the time people informed authorities of the disaster, and interviews with residents. The field surveys include investigations of the extent of affected areas and the damage caused to residences and infrastructures. These reports classify disasters into three types: landslides, debris flows, and floods. As landslides and debris flows are characterized by different processes, they are separated in the analysis to help identify the triggers associated with each type of failure. Only a few cases of gravity-driven falls or topples were reported, and all such events occurred during a dry period with almost no rainfall. Therefore, we carefully checked all reports $(n=292)$ and excluded events not caused by rainfall (almost no rainfall during mass movements). 


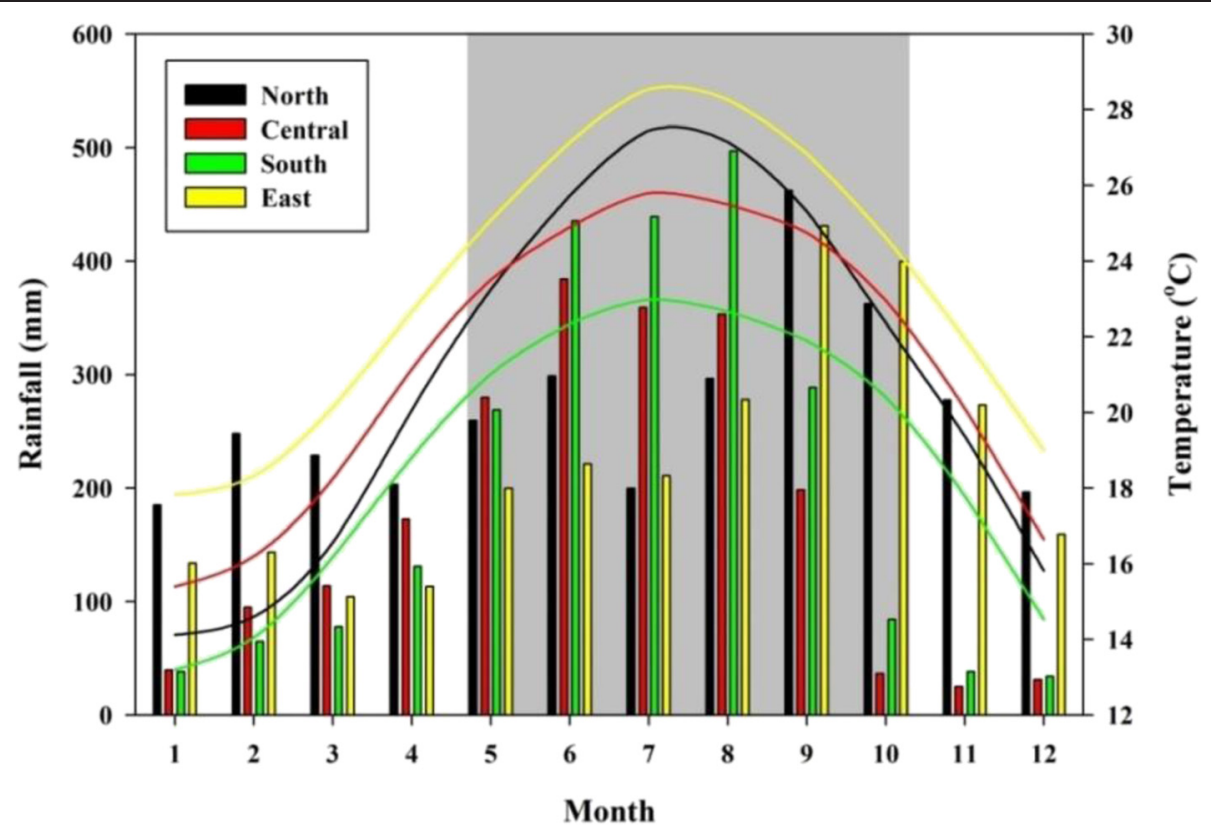

Fig. 2 Average monthly temperature (curved lines) and rainfall (bars) in different regions of Taiwan (averaged from 1981 to 2010). North Taipei, Keelung, Taoyuan, Hsinchu, and Miaoli; Central Taichung, Changhua, Nantou, and Yunlin; South Chiayi, Tainan, Kaohsiung, and Pingtung; East llan, Hualien, and Taitung

Although mass movements occur frequently in Taiwan, there is currently no complete inventory that can provide detailed information about these events. As SWCB data have a relatively high level of integrity and consistency, it is the best source of information to compile an inventory and analyze the relationships between mass movements and rainfall conditions in Taiwan.

\section{Rainfall data}

Taiwan's Central Weather Bureau has installed more than 400 rain gauges to record hourly data with a density of approximately one gauge every $76 \mathrm{~km}^{2}$ (Fig. 3). Since rain gauges are not always located close to mass movement sites, we selected the nearest five rain gauges for each mass movement and conducted a kriging interpolation to estimate rainfall at each mass movement location. This technique uses ordinary kriging and a spherical semivariogram model with a variable search radius to estimate hourly rainfall data at each site over the duration of a rainfall event. A continuous rainfall event is considered to begin when hourly rainfall surpasses $4 \mathrm{~mm}$ and ends when hourly rainfall decreases below $4 \mathrm{~mm}$ over the next six consecutive hours (e.g., Chang et al. 2011).

We calculated the mean rainfall intensity $(I, \mathrm{~mm} / \mathrm{h})$, rainfall duration $(D, \mathrm{~h})$, and peak rainfall intensity $(\mathrm{mm} / \mathrm{h})$ from the beginning of each rainfall event to the time of mass movement occurrence. Some previous studies have used 1 week of antecedent rainfall for analyzing the antecedent soil moisture and found that it is an important factor for triggering landslides (Crosta 1998; Jakob 2006). Therefore, we also examined rainfall totals for $168 \mathrm{~h}$ ( 1 week) before the beginning of rainfall events that triggered mass movement events.

\section{I-D thresholds}

The $I-D$ threshold for mass movements is identified on an $I-D$ plot as the minimum rainfall total for which a mass movement could occur (e.g., Guzzetti et al. 2007). In early years, the lower rainfall boundary (threshold) was determined manually (e.g., Caine 1980; Larsen and Simon 1993; Chien-Yuan et al. 2005). However, more recently, mathematical and/or statistical criteria have been used to objectively determine the lower boundary. Guzzetti et al. (2007) were the first to propose the Bayesian inference method for determining $I-D$ thresholds; Brunetti et al. (2010) proposed a frequentist approach; and Saito et al. (2010a) adopted the quantile-regression method.

Although many different methods have been proposed, the general form of the relationship between rainfall intensity and duration is:

$$
I=\alpha D^{-\beta}
$$

where $\alpha$ is a scaling constant (intercept), and $\beta$ is the shape parameter (slope).

Like all landslide inventories, data analyzed in this study contain inherent uncertainties, including measurement errors, erosional or geographical censoring, and reporting biases (Kirschbaum et al. 2012; Korup et al. 2012; Petley 


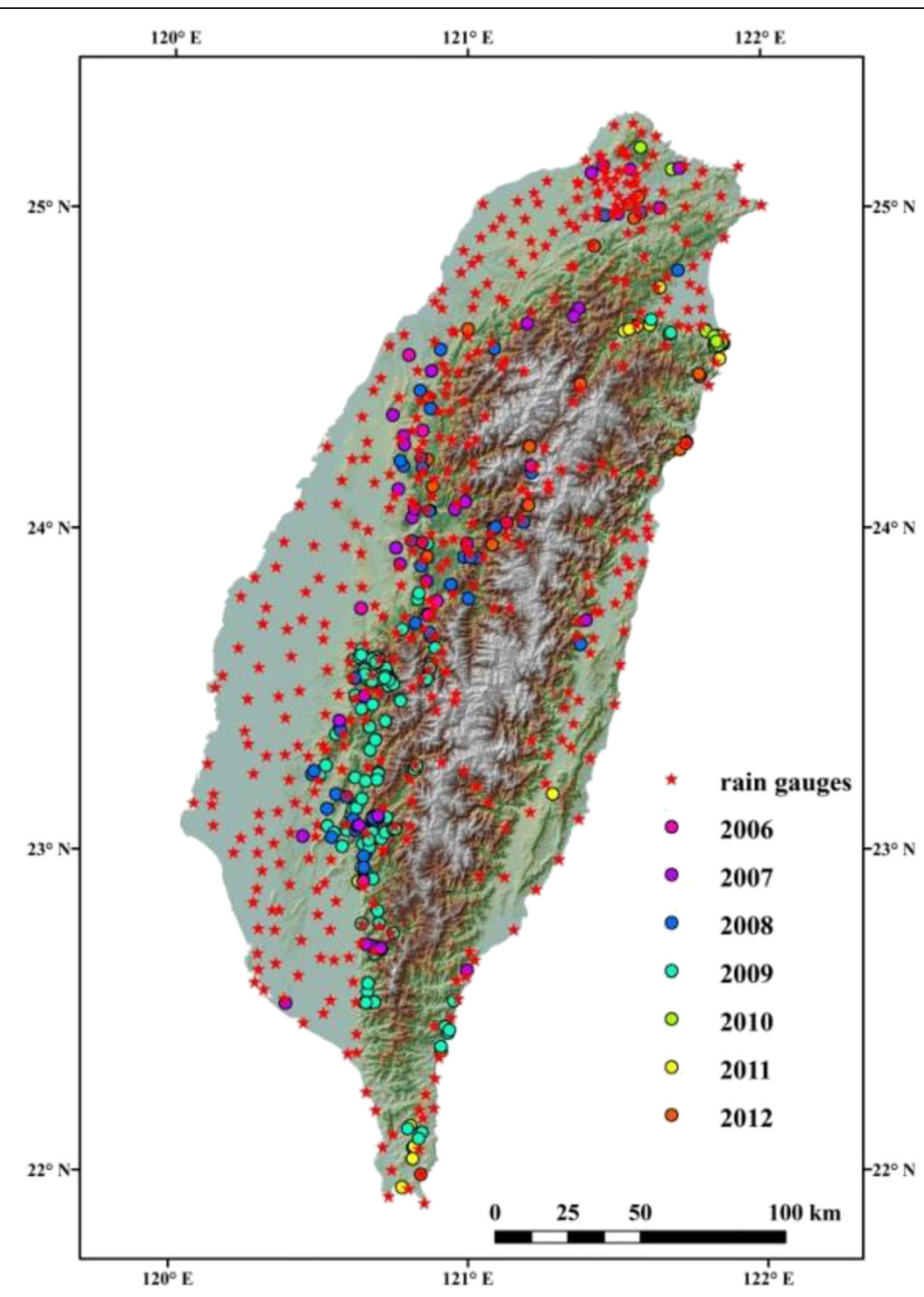

Fig. 3 Distribution of rain gauges and mass movements that occurred between 2006 and 2012

2012). We therefore determined thresholds by the frequentist statistical method and the random sampling method, which are statistically robust approaches. Brunetti et al. (2010) suggested the frequentist statistical method for the definition of objective empirical-rainfall thresholds. Following this method, the standard $I-D$ threshold was defined as $5 \%$. We also used the robust random sampling method due to its resistance to errors and outliers. To establish the threshold equation, two-thirds of the data were randomly sampled, and this was repeated 100 times, allowing us to calculate the mean and standard deviation of $\alpha$ and $\beta$ in Eq. (1).

Regional $I-D$ thresholds are limited by their specificity to a certain region. They cannot be easily applied to other areas because topographic, lithological, meteorological, and climatological characteristics may vary between regions (Jakob and Weatherly 2003; Guzzetti et al. 2007, 2008). For example, limited surface vegetation and the accumulation of regolith on slopes during long dry periods allow a relatively short and weak rainfall event to initiate mass movements in arid areas. Therefore, rainfall intensity $(I)$ was divided by mean annual precipitation (MAP) (Aleotti 2004; Guzzetti et al. 2007, 2008; Dahal and Hasegawa 2008; Saito et al. 2010a) to offset regional effects and obtain comparable rainfall thresholds for different areas. The relationship between rescaled rainfall intensity $\left(I_{\mathrm{MAP}}\right)$ and rainfall duration $\left(I_{\mathrm{MAP}}-D\right.$ condition) was analyzed using the same procedure described for raw values.

The MAP of mountainous areas in Taiwan is greater than $3000 \mathrm{~mm}$ but varies spatially (Shieh 2000). Therefore, for mountainous regions, $I_{\text {MAP }}$ is conservatively estimated by dividing $I$ by $3000 \mathrm{~mm}$. The $I-D$ and $I_{\mathrm{MAP}}-D$ thresholds for Taiwan were then compared with 
previously reported threshold values compiled by Saito et al. (2010a).

\section{Time between mass movements and peak rainfall intensity}

To account for the effect of temporal rainfall intensity variations on mass movements, we calculated the time difference $\left(T_{\mathrm{d}}\right)$ between mass movements and peak rainfall intensity (maximum hourly rainfall) as follows:

$T_{d}=$ time of a mass movement - time of peak rainfall intensity

Positive $T_{\mathrm{d}}$ values indicate that mass movements occurred after peak rainfall intensity, and negative $T_{\mathrm{d}}$ values indicate that mass movements occurred before peak rainfall intensity.

\section{Results}

\section{Rainfall conditions and $I-D$ thresholds}

Mean rainfall intensity for all mass movements ranged from 8.9 to $64.8 \mathrm{~mm} / \mathrm{h}$ with an average of $21.7 \mathrm{~mm} / \mathrm{h}$, and rainfall duration ranged between 2 and $71 \mathrm{~h}$ with an average of $33.2 \mathrm{~h}$. Cumulative rainfall was as low as $60.3 \mathrm{~mm}$ and as high as $1916.5 \mathrm{~mm}$ with an average of $668.8 \mathrm{~mm}$. Antecedent rainfall was between 1.8 and $707.7 \mathrm{~mm}$ with an average of $124.9 \mathrm{~mm}$ (Table 1). The $I-D$ correlation (Fig. 4) shows that an increase in rainfall duration results in a reduction in the rainfall intensity required to trigger a mass movement.

Average rainfall intensity, duration, cumulative rainfall, and antecedent rainfall for debris flows were $23.2 \mathrm{~mm} / \mathrm{h}$, $33.5 \mathrm{~h}, 692.6 \mathrm{~mm}$, and $101.1 \mathrm{~mm}$, respectively, and those for landslides were $20.7 \mathrm{~mm} / \mathrm{h}, 32.5 \mathrm{~h}, 652.4 \mathrm{~mm}$, and $142.2 \mathrm{~mm}$, respectively (Table 1 ). A $t$-test and resultant $p$-values indicate that mean rainfall intensity and antecedent rainfall are significantly different for landslides and debris flows (Table 1). Figure 4 also shows that the
$I-D$ regression line for debris flows is higher than the $I-$ $D$ regression line for landslides.

Figure 5 shows the time difference $\left(T_{\mathrm{d}}\right)$ between mass movements and peak rainfall intensity. Approximately $16 \%$ of mass movements occurred very close to the time of peak rainfall intensity (within $\pm 30 \mathrm{~min}$ ), and most mass movements (75\%) occurred within $7 \mathrm{~h}$ of peak rainfall intensity.

As previously stated, we utilized the frequentist method with random sampling to delineate the $I-D$ thresholds for all mass movements, landslides only, and debris flows only (Fig. 4). The resultant equations for these three conditions are as follows:

$I=18.10( \pm 2.67) D^{-0.17\left({ }^{ \pm 0.04}\right)}(2 \leq D \leq 71 \mathrm{~h} ;$ all mass movements $)$,

$I=13.25( \pm 2.76) D^{-0.08\left({ }^{ \pm 0.06}\right)}(2 \leq \mathrm{D} \leq 71 \mathrm{~h}$; landslides only $)$, and

$I=26.92( \pm 6.67) D^{-0.26\left({ }^{ \pm 0.07}\right)}(2 \leq D \leq 68 \mathrm{~h}$; debris flows only $)$.

The equation for all mass movements (Eq. 3) indicates that short-duration (e.g., $<2 \mathrm{~h}$ ) and high-intensity (e.g., $>16.1 \mathrm{~mm} / \mathrm{h}$ ) rainfall events can potentially trigger mass movements. However, long-duration (e.g., $>71$ h) and low-intensity (e.g., $<8.8 \mathrm{~mm} / \mathrm{h}$ ) rainfall events may also trigger mass movements. Figure 6 shows $I-D$ thresholds for Taiwan and other global areas from Saito et al. (2010a). This shows that the $I-D$ threshold for Taiwan is generally higher than that of other areas.

\section{$I_{\text {MAP }}-D$ thresholds}

Figure 7 shows the $I_{\mathrm{MAP}}-D$ thresholds for Taiwan. The new thresholds for all mass movements, landslides only,

Table 1 Rainfall conditions

\begin{tabular}{|c|c|c|c|c|c|c|c|c|}
\hline \multirow{3}{*}{$\begin{array}{l}\text { Rainfall } \\
\text { conditions }\end{array}$} & \multicolumn{2}{|c|}{ Mean intensity (mm/h) } & \multicolumn{2}{|c|}{ Duration (h) } & \multicolumn{2}{|c|}{ Cumulative rainfall (mm) } & \multicolumn{2}{|c|}{ Antecedent rainfall (mm) } \\
\hline & \multicolumn{2}{|c|}{ Mass movements } & \multicolumn{2}{|c|}{ Mass movements } & \multicolumn{2}{|c|}{ Mass movements } & \multicolumn{2}{|c|}{ Mass movements } \\
\hline & Landslides & Debris flows & Landslides & Debris flows & Landslides & Debris flows & Landslides & Debris flows \\
\hline \multirow[t]{3}{*}{ Average } & \multicolumn{2}{|c|}{21.7} & \multicolumn{2}{|c|}{33.2} & \multicolumn{2}{|c|}{668.8} & \multicolumn{2}{|c|}{124.9} \\
\hline & 20.7 & 23.2 & 32.5 & 33.5 & 652.4 & 692.6 & 142.2 & 101.1 \\
\hline & \multicolumn{2}{|c|}{$p<0.05$} & \multicolumn{2}{|c|}{$p>0.05$} & \multicolumn{2}{|c|}{$p>0.05$} & \multicolumn{2}{|c|}{$p<0.05$} \\
\hline \multirow[t]{2}{*}{ Max. } & \multicolumn{2}{|c|}{64.8} & \multicolumn{2}{|c|}{71.0} & \multicolumn{2}{|c|}{1916.5} & \multicolumn{2}{|c|}{707.7} \\
\hline & 64.8 & 58.8 & 71.0 & 68.0 & 1733.5 & 1916.5 & 707.3 & 707.7 \\
\hline \multirow[t]{2}{*}{ Min. } & \multicolumn{2}{|c|}{8.9} & \multicolumn{2}{|c|}{2.0} & \multicolumn{2}{|c|}{60.3} & \multicolumn{2}{|c|}{1.8} \\
\hline & 8.9 & 9.9 & 2.0 & 2.0 & 60.3 & 64.0 & 1.8 & 3.5 \\
\hline
\end{tabular}




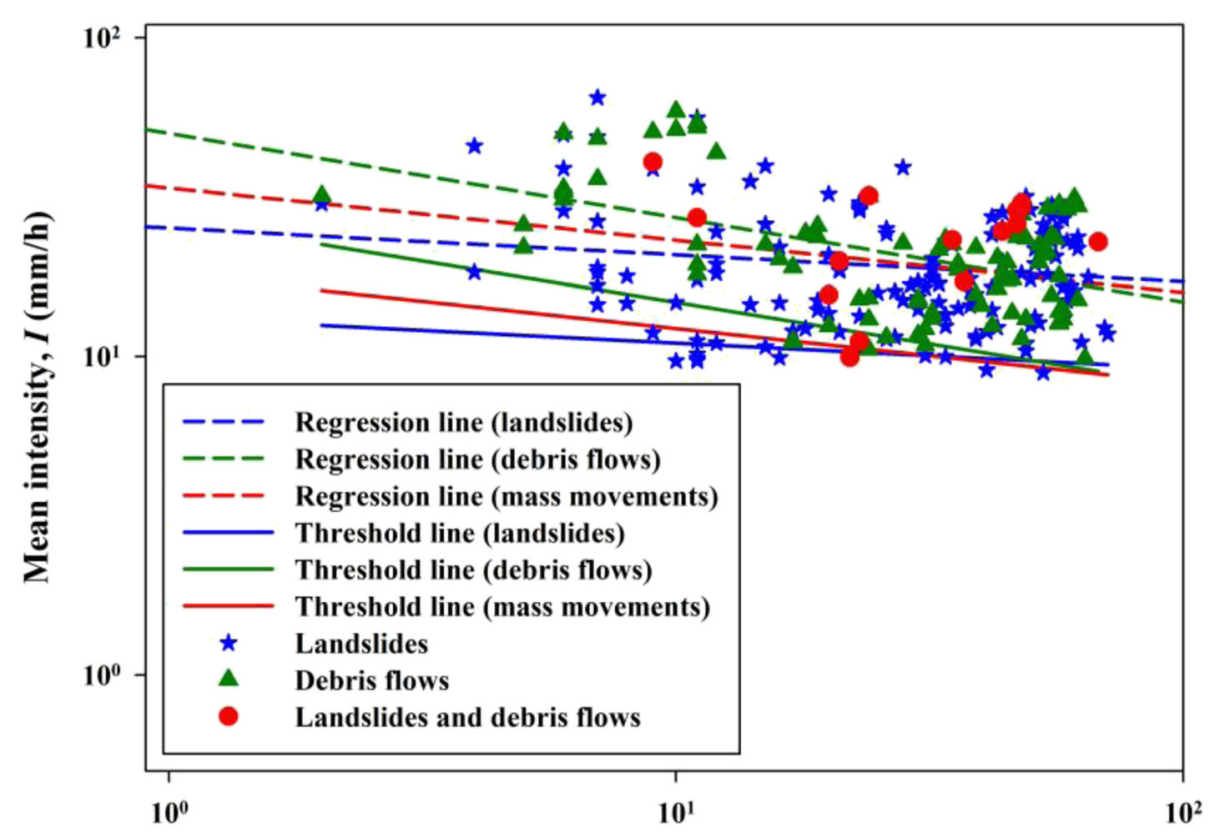

Duration, $D$ (h)

Fig. 4 I-D correlations and thresholds for all mass movements, landslides only, and debris flows only

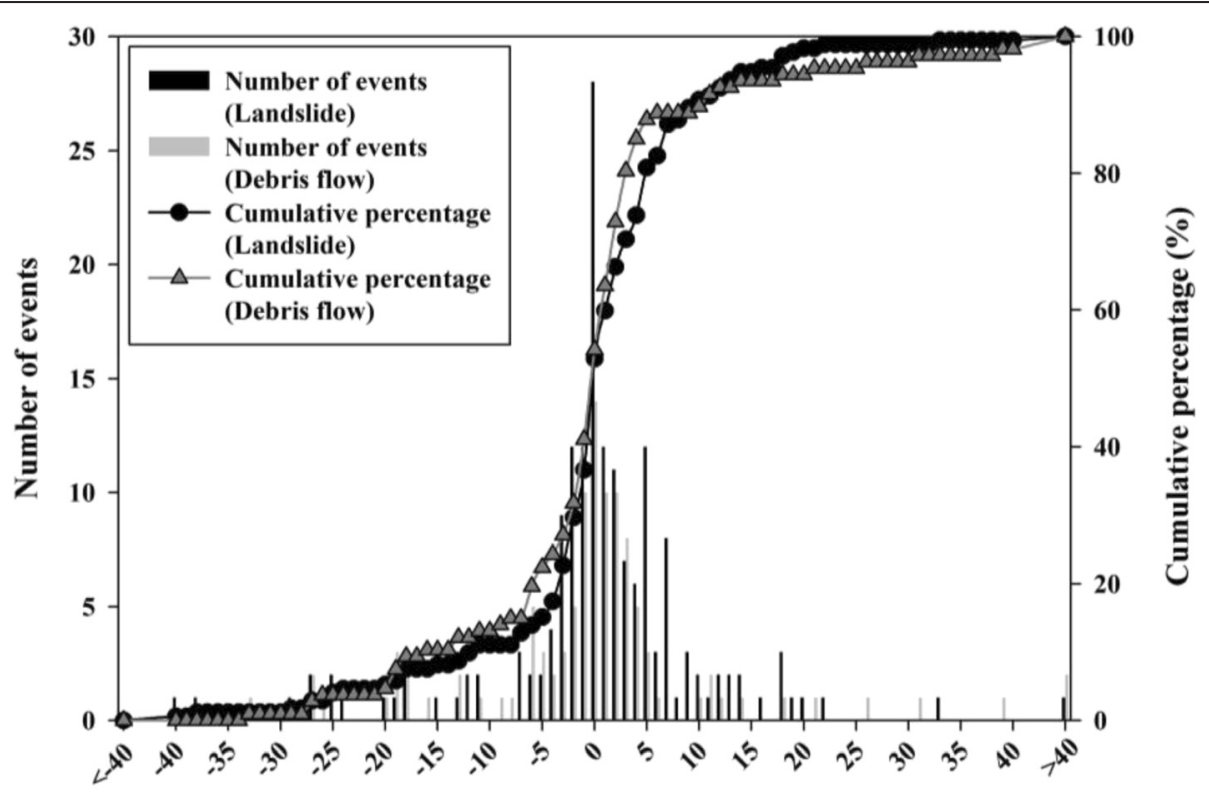

Time difference (h)

Fig. 5 Time difference between mass movement occurrence and peak rainfall intensity 


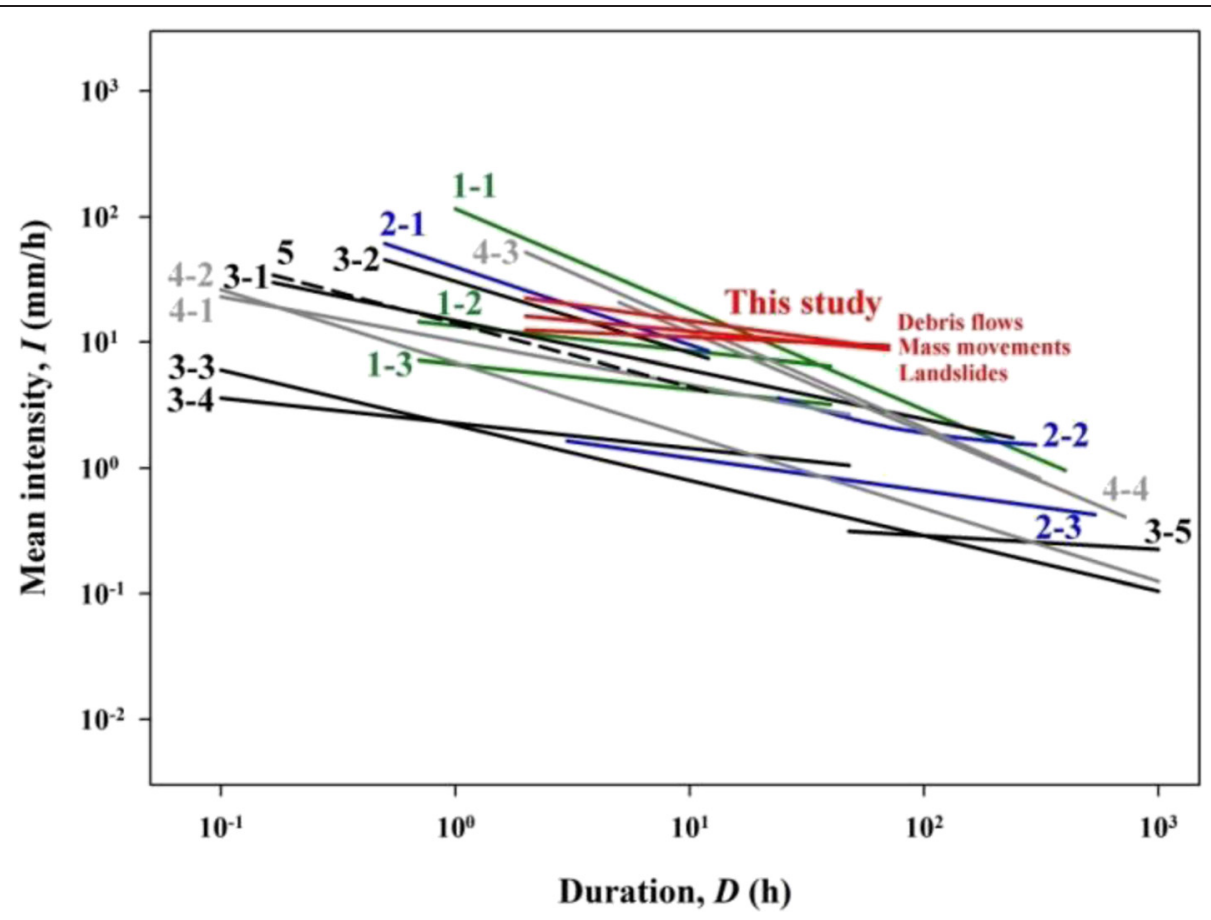

Fig. 6 Comparison of I-D thresholds. Green lines thresholds for Taiwan. Blue lines thresholds for Japan. Black lines global thresholds. Gray lines thresholds for humid (sub)tropics or Asian monsoon regions. Dashed line other regional thresholds. 1-1 Chien-Yuan et al. (2005); 1-2 and 1-3 Jan and Chen (2005); 2-1 and 3-2 Jibson (1989); 2-2 Hong et al. (2005); 2-3 Saito et al. (2010a); 3-1 Caine (1980); 3-3, 3-4, and 3-5 Guzzetti et al. (2008); 4-1 and 4-2 Guzzetti et al. (2008), Cfa climate of humid subtropical east coast in Köppen's system; 4-3 Larsen and Simon (1993), Puerto Rico; 4-4 Dahal and Hasegawa (2008), Nepal Himalaya; 5 Cannon et al. (2008), Southern California

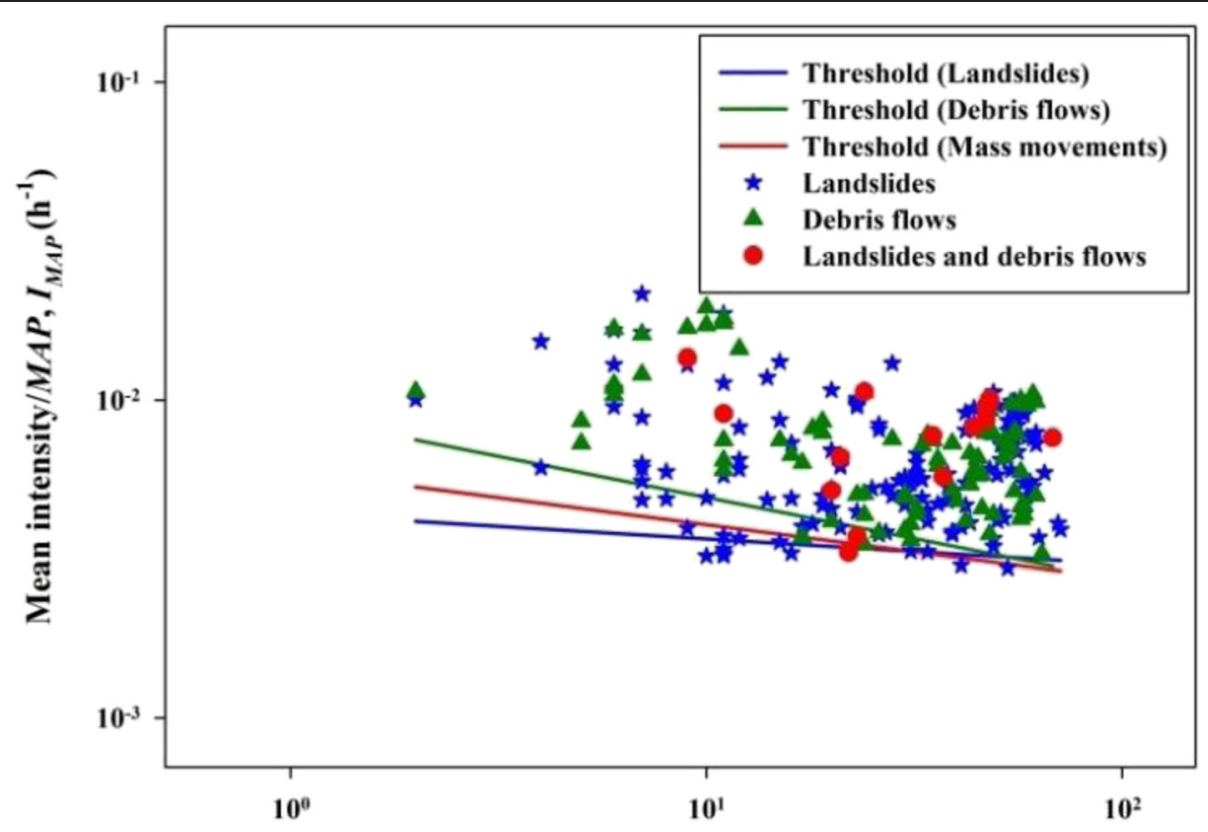

Duration, $D$ (h)

Fig. $7 I_{\text {MAP }}-D$ thresholds for all mass movements, landslides only, and debris flows only 
and debris flows only are described by the following equations:

$I_{\text {MAP }}=0.0060( \pm 0.0009) D^{-0.17\left({ }^{ \pm 0.04}\right)}(2 \leq D \leq 71 \mathrm{~h} ;$ allmass movements $)$,

$I_{\mathrm{MAP}}=0.0044( \pm 0.0009) D^{-0.08\left({ }^{(0.06}\right)}(2 \leq D \leq 71 \mathrm{~h}$; landslides only $)$, and

$I_{\mathrm{MAP}}=0.0090( \pm 0.0022) D^{-0.26\left({ }^{ \pm 0.07}\right)}(2 \leq D \leq 68 \mathrm{~h} ;$ debris flows only $)$

Figure 8 shows the $I_{\mathrm{MAP}}-D$ threshold for mass movements in Taiwan alongside data from Saito et al. (2010a). After rescaling, the $I_{\mathrm{MAP}}-D$ threshold for Taiwan is generally lower than that of other areas (Fig. 8).

\section{Differences in thresholds for landslides and debris flows}

$I-D$ and $I_{\mathrm{MAP}}-D$ thresholds for landslides and debris flows show that debris flows tend to occur during more severe (high intensity) rainfall conditions than landslides. In addition, $t$-tests show that the $\alpha$ and $\beta$ of $I-D$ and $I_{\mathrm{MAP}}-D$ thresholds for landslides (Eqs. 4 and 6) and debris flows (Eqs. 5 and 7) are statistically different at the $5 \%$ significance level. However, Figs. 4 and 7 also demonstrate that the $I-D$ correlations and thresholds for landslides and debris flows become closer as $D$ increases, and their difference becomes negligible once $D$ reaches approximately $50 \mathrm{~h}$.

\section{Discussion}

\section{$I-D$ and $I_{\text {MAP }}-D$ conditions and thresholds for landslides} and debris flows

The difference in $I-D$ and $I_{\mathrm{MAP}}-D$ thresholds between landslides and debris flows, as well as data in Table 1, indicate that a higher mean rainfall intensity is required to flush surface materials and cause a debris flow for shortduration rainfall events. We rule out reporting biases from our mass movement inventory based on unaltered trends obtained using the frequentist statistical and random sampling methods. Our results reflect the fact that high water levels in channels and streams are required to trigger a debris flow. A long-duration rainfall event leads to a gradual increase in groundwater level, soil moisture, and pore water pressure (Wieczorek and Glade 2005), and this leads to the concurrent increase in surface flow in channels and streams. Therefore, similar rainfall intensity levels can trigger both landslides and debris flows if rainfall duration is sufficiently long. In addition, landslides may completely or partially mobilize to form debris flows (Iverson et al. 1997), as was the case in the 16 events in which a landslide and debris flow both occurred (Figs. 4 and 7).

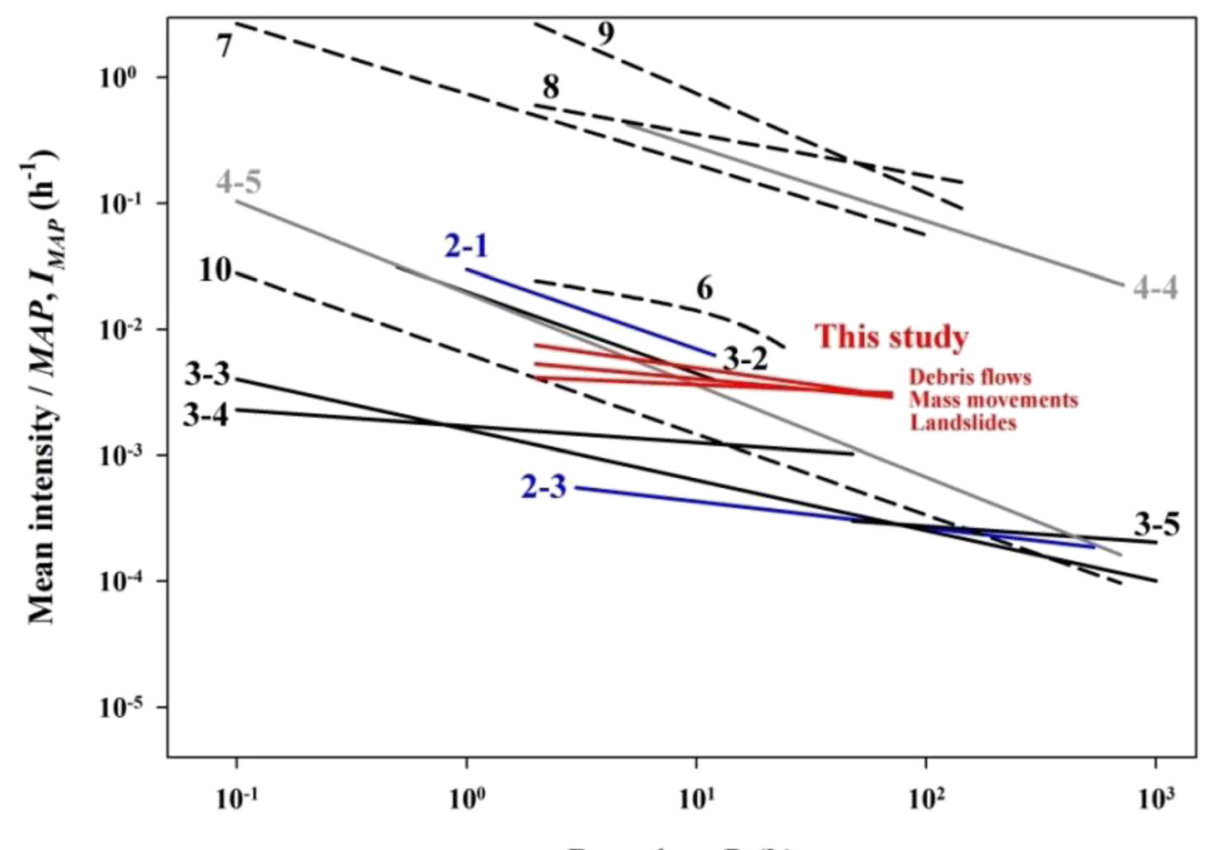

Duration, $D$ (h)

Fig. 8 Comparison of $I_{\text {MAP }}-D$ thresholds. Blue lines thresholds for Japan. Black lines global thresholds. Gray lines thresholds for humid (sub)tropics or Asian monsoon regions. Dashed lines other regional thresholds. 2-1 and 3-2 Jibson (1989); 2-3 Saito et al. (2010a); 3-3, 3-4, and 3-5: Guzzetti et al. (2008); 4-4 Dahal and Hasegawa (2008), Nepal Himalaya; 4-5 Guzzetti et al. (2007), mild mid-latitude climates; 6 Cannon (1988), San Francisco; 7 Bacchini and Zannoni (2003), Cancia, Dolomites, Italy; 8 and 9 Aleotti (2004), Piedmont, Italy; 10 Guzzetti et al. (2007), Central and Southern Europe 


\section{Comparing $I-D$ and $I_{\text {MAP }}-D$ thresholds for Taiwan with those of other areas}

Jan and Chen (2005) established thresholds for debris flows in the Chenyoulan river catchment in central Taiwan before and after the 1999 Chi-Chi earthquake. The threshold determined in this study for the whole of Taiwan is similar to the threshold for the Chenyoulan river catchment before the Chi-Chi earthquake (1-2 in Fig. 6), lower than the threshold for Taiwan from 1989 to 2001 (1-1 in Fig. 6), and higher than the threshold for the Chenyoulan river catchment just after the ChiChi earthquake (1-3 in Fig. 6). These results suggest that the rainfall threshold for mass movements in Taiwan decreased in 1999 when the Chi-Chi earthquake generated an enormous quantity of loose material, which resulted in a rapid decrease of the mass movement rainfall threshold for this region. Our results indicate that the threshold recovered to pre-earthquake values during 2006-2012. Many previous studies reported similar decreases in both the maximum rainfall intensity and critical cumulative rainfall required to trigger mass movements after the Chi-Chi earthquake. As observed in this study, these values gradually returned to preearthquake conditions after several years (Lin et al. 2003; Chang et al. 2009; Shieh et al. 2009; Chen 2011).

The slope of the rainfall threshold line for debris flows determined in this study is similar to the value calculated by Jan and Chen (2005) but quite different from the $I-D$ threshold value reported in Chien-Yuan et al. (2005). The later study utilized data from 61 debris flows between 1989 and 2001, obtained from newspapers and interviews with local residents, and the $I-D$ threshold was determined visually rather than statistically. The differences in threshold line slope between our study and Chien-Yuan et al. (2005) are likely attributable to their relatively small sample size and subjective method for establishing $I-D$ thresholds. Comparatively, we determined the $I-D$ threshold using 107 debris flow events and employed statistical methods to ensure the validity of our results. Nevertheless, our study along with results from Chien-Yuan et al. (2005) and Jan and Chen (2005) all show debris flow thresholds larger than landslide thresholds.

Comparing our $I-D$ thresholds with those from other areas of the world shows that the $I-D$ threshold for Taiwan is relatively high, particularly for long-duration rainfall events (Fig. 6). As Taiwan is characterized by high-relief topography and complex geology (Fig. 1), both of which facilitate mass movements, this observation seems contradictory. In Taiwan, high cumulative precipitation amounts and frequent heavy storms, particularly those associated with typhoons (Wu and Kuo 1999), have created landforms that are well adjusted to the extreme climatic conditions of the region. Therefore, since unconsolidated hillslope materials are limited, strong rainfall is needed to trigger mass movements.

Several studies on mass movements in Japan also found that hillslopes in regions with high cumulative precipitation displayed greater resistance to rainfall than hillslopes in regions with low cumulative precipitation (Omura 1980, 1982). Saito and Matsuyama (2012) confirmed this for Japan using MAP data. They found that because the MAP is extremely high in the eastern part of the Kii Peninsula, Japan, it is not prone to landslides even with the high cumulative rainfall and maximum hourly rainfall intensity due to typhoon events. The resistance of the landscape in Taiwan to mass movements therefore explains the higher $I-D$ threshold relative to other areas of the world. In addition, the gentle slope of the threshold in Taiwan suggests that rainfall intensity plays a much more important role in triggering mass movements, This observation further confirms the above statement that landforms are well adjusted to the extreme climatic conditions.

As indicated above, the $I_{\mathrm{MAP}}-D$ threshold is useful for eliminating biases caused by variable rainfall conditions. Even though we used a relatively conservative MAP value of $3000 \mathrm{~mm}$ to rescale the data, the $I_{\mathrm{MAP}}-D$ threshold for Taiwan was generally lower than in other areas. Therefore, the steep topography and highly deformed underlying bedrock of Taiwan likely contribute to frequent mass movements in the region. In summary, analysis of both $I-$ $D$ and $I_{\mathrm{MAP}}-D$ thresholds is useful for examining the effects of topography, geology, and hillslope adjustment to rainfall conditions on mass movements.

\section{Mass movements in relation to rainfall peaks and antecedent rainfall}

$I-D$ plots represent average rainfall event conditions and do not necessarily reflect high rainfall intensities at the time of mass movement occurrence. Therefore, it is difficult to predict the exact time of a mass movement using only $I-D$ thresholds. Many studies have found that peak rainfall intensity occurs very close to the time of mass movement occurrence (Aleotti 2004; Chien-Yuan et al. 2005; Guzzetti et al. 2007, 2008; Dahal and Hasegawa 2008; Saito et al. 2010a, 2010b). Thus, analyzing peak rainfall intensity in conjunction with $I-D$ thresholds is useful for characterizing mass movements.

Most mass movement occurrences investigated were concentrated around the time of peak rainfall intensity; approximately $75 \%$ of mass movements occurred within $7 \mathrm{~h}$ of peak rainfall (Fig. 5). To focus on the remaining $25 \%$ of mass movements that occurred more than $7 \mathrm{~h}$ before or after peak rainfall, we classified mass movements into three groups: $T_{\mathrm{d}}<-7$ (group $1=\mathrm{G} 1$ ), $T_{\mathrm{d}}=-7$ to 7 (G2), and $T_{\mathrm{d}}>$ 7 (G3). Table 2 shows average peak intensity, mean 
Table 2 Average rainfall conditions for different $T_{d}$ groups. Italic values show groups with significantly higher values using a $t$-test $(p<0.05)$

\begin{tabular}{|c|c|c|c|c|c|c|c|c|}
\hline \multirow[t]{2}{*}{ Rainfall condition groups } & \multicolumn{2}{|c|}{ Peak intensity $(\mathrm{mm} / \mathrm{h})$} & \multicolumn{2}{|c|}{ Mean intensity $(\mathrm{mm} / \mathrm{h})$} & \multicolumn{2}{|c|}{ Duration (h) } & \multicolumn{2}{|c|}{ Antecedent rainfall (mm) } \\
\hline & Landslides & Debris flows & Landslides & Debris flows & Landslides & Debris flows & Landslides & Debris flows \\
\hline $\mathrm{G} 1: T_{\mathrm{d}}<-7(n=19,16)$ & 71.5 & 65.6 & 16.8 & 13.7 & 32.6 & 29.9 & 79.4 & 102.0 \\
\hline $\mathrm{G} 2: T_{d}=-7$ to $7(n=131,79)$ & 80.7 & 90.3 & 21.9 & 25.9 & 30.8 & 32.2 & 159.3 & 90.1 \\
\hline $\mathrm{G} 3: T_{d}>7(n=22,12)$ & 60.4 & 56.6 & 18.7 & 18.1 & 45.6 & 46.9 & 94.7 & 172.0 \\
\hline
\end{tabular}

intensity, duration, and antecedent rainfall for these three groups.

G2 has the highest peak and mean rainfall intensities for both landslides and debris flows, and rainfall values tend to be significantly different from the other groups. Antecedent rainfall for landslides in G2 is also significantly higher than other groups. This indicates that G2 is composed primarily of landslides, with release mechanisms directly related to hillslope hydrology. Soil moisture content is directly related to landslide occurrence (Terlien 1998; Wu and Chen 2009), and high antecedent rainfall elevates moisture content (Glade 1997; Crosta 1998; Crozier 1999; Glade et al. 2000; Jakob 2006). Therefore, abundant antecedent rainfall combined with high-intensity rainfall can easily trigger landslides, especially around the time of peak rainfall. In addition, during or just after peak rainfall, high-intensity rainfall flushes large amounts of debris into rivers, triggering debris flows. In this case, abundant antecedent rainfall is not a requirement because debris flows can be triggered by riverbed material saturated with surface water (Berti et al. 1999; Coe et al. 2008), not necessarily hillslope material saturated with underground soil water.

G3 has the longest rainfall duration for both landslides and debris flows. Although G3 events are characterized by low peak and mean rainfall intensities, rainfall durations are relatively long, resulting in mass movements long after peak rainfall. Terlien (1998) also showed that when there is no significant antecedent rainfall and rainfall intensity is low, a long-duration rainfall event is required to trigger landslides with high soil moisture content.

According to Table 2, G1 events are associated with relatively short-duration rainfall, with low peak and mean rainfall intensities, and low antecedent rainfall, meaning that mass movements occurred in spite of these conditions. This is an unexpected result; our first assumption was that mass movements well before the rainfall peak must reflect abundant antecedent rainfall, which was found to be invalid. For G1, the role of factors other than rainfall, such as local topography or geology highly susceptible to mass movements, seems to be more important. However, the result may also be due to the definition of antecedent rainfall. Although antecedent rainfall was calculated over a period of $168 \mathrm{~h}$, even earlier rainfall might have played a key role in triggering the G1 mass movements. Indeed, the definition of antecedent rainfall is a difficult task (Crozier 1999; Glade et al. 2000; Dahal and Hasegawa 2008), and future research is needed to refine this definition and further investigate the effect of topographical and geological factors in triggering mass movements.

\section{Conclusions}

This study established empirical $I-D$ thresholds for mass movements in Taiwan from landslide and debris flow data, and these thresholds were compared with those for other areas of the world. For short-duration rainfall events, higher mean rainfall intensities were required to trigger debris flows, while long-duration rainfall events can trigger both landslides and debris flows with almost the same rainfall intensity. $I-D$ thresholds for mass movements in Taiwan tended to be higher than those for other areas, but the rescaled $I_{\mathrm{MAP}}-D$ thresholds (in which rainfall intensity was rescaled using a MAP of $3000 \mathrm{~mm}$ ) tended to be lower. These results reflect the rainfall characteristics of the region along with the topographic and geological conditions of Taiwan.

This study also demonstrated the importance of peak rainfall intensity. Most mass movements (74.9 \%) occurred within $7 \mathrm{~h}$ of peak rainfall. Antecedent rainfall and saturated hillslope material are also important for triggering landslides, but antecedent rainfall is less important in triggering debris flows from river bed material. Other events that occurred significantly before or after peak rainfall may be related to the rainfall duration and non-meteorological factors such as local topography and geology. Further studies are necessary to investigate $I-D$ thresholds and related issues in more detail.

\section{Abbreviations}

I: rainfall intensity; D: rainfall duration; SWCB: Soil and Water Conservation Bureau; MAP: mean annual precipitation; I MAP: rescaled rainfall intensity using mean annual precipitation; $T_{\mathrm{d}}$ : time difference between mass movements and peak rainfall intensity.

\section{Competing interests}

The authors declare that they have no competing interests.

\section{Authors' contributions}

CC collected the data, performed the statistical analysis, and drafted the manuscript. HS participated in the design of the study, provided statistical methods, and helped to draft the manuscript. TO conceived of the study, participated in its design and coordination, and helped to draft the manuscript. All authors read and approved the final manuscript. 


\section{Acknowledgements}

We would like to thank the Typhoon and Flood Research Institute (TTFRI) of Taiwan for providing rainfall data. We would also like to thank the Soil and Water Conservation Bureau (SWCB) of Taiwan for providing mass movement data.

\section{Author details}

${ }^{1}$ Department of Natural Environmental Studies, Graduate School of Frontier Science, The University of Tokyo, 5-1-5 Kashiwanoha, Kashiwa Chiba 277-8568, Japan. ${ }^{2}$ College of Economics, Kanto Gakuin University, 1-5-1 Mutsuura-higashi, Yokohama, Kanagawa 236-8501, Japan. ${ }^{3}$ Center for Spatial Information Science, University of Tokyo, 5-1-5 Kashiwanoha, Kashiwa Chiba 277-8568, Japan.

Received: 10 February 2015 Accepted: 2 June 2015

\section{Published online: 19 June 2015}

\section{References}

Aleotti P (2004) A warning system for rainfall-induced shallow failures. Eng Geol 73:247-265. doi:10.1016/j.enggeo.2004.01.007

Aleotti P, Chowdhury R (1999) Landslide hazard assessment: summary review and new perspectives. Bull Eng Geol Env 58:21-44. doi:10.1007/s100640050066

Bacchini M, Zannoni A (2003) Relations between rainfall and triggering of debris-flow: case study of Cancia (Dolomites, Northeastern Italy). Natural Hazard Earth Sys 3:71-79. doi:10.5194/nhess-3-71-2003

Berti M, Genevois R, Simoni A, Tecca PR (1999) Field observations of a debris flow event in the Dolomites. Geomorphology 29:265-274. doi:10.1016/S0169$555 \times(99) 00018-5$

Brunetti MT, Peruccacci S, Rossi M, Luciani S, Valigi D, Guzzetti F (2010) Rainfall thresholds for the possible occurrence of landslides in Italy. Nat Hazards Earth Syst Sci 10:447-458. doi:10.5194/nhess-10-447-2010

Caine N (1980) The rainfall intensity-duration control of shallow landslides and debris flows. Geogr Ann A 62:23-27. doi:10.2307/520449

Cannon S (1988) Regional rainfall-threshold conditions for abundant debris-flow activity. In: Ellen SD, Wieczorek GF (eds) Landslides, floods, and marine effects of the storm of January 3-5, 1982, in the San Francisco Bay Region, California. US Geological Survey Professional Paper, vol 1434:35-42

Cannon S, Gartner J, Wilson R, Bowers J, Laber J (2008) Storm rainfall conditions for floods and debris flows from recently burned areas in southwestern Colorado and southern California. Geomorphology 96:250-269. doi:10.1016/ j.geomorph.2007.03.019

Chang CW, Lin PS, Tsai CL (2011) Estimation of sediment volume of debris flow caused by extreme rainfall in Taiwan. Eng Geol 123:83-90. doi:10.1016/ j.enggeo.2011.07.004

Chang FJ, Chiang YM, Lee WS (2009) Investigating the impact of the Chi-Chi earthquake on the occurrence of debris flows using artificial neural networks. Hydrol Process 23:2728-2736. doi:10.1002/hyp.7369

Chang JC, Slaymaker O (2002) Frequency and spatial distribution of landslides in a mountainous drainage basin: Western Foothills, Taiwan. Catena 46:285-307. doi:10.1016/S0341-8162(01)00157-6

Chang K, Chiang S (2009) An integrated model for predicting rainfall-induced landslides. Geomorphology 105:366-373. doi:10.1016/j.geomorph.2008.10.012

Chen $\mathrm{H}$, Chen RH, Lin ML (1999) Initiative anatomy of Tungmen debris flow, eastern Taiwan. Environ Eng Geosci 5:459-473. doi:10.2113/ gseegeosci.V.4.459

Chen H, Su DI (2001) Geological factors for hazardous debris flow in Hoser, central Taiwan. Environ Geol 40:1114-1124. doi:10.1007/s002540100312

Chen JC (2011) Variability of impact of earthquake on debris-flow triggering conditions: case study of Chen-Yu-Lan watershed, Taiwan. Environ Earth Sci 64:1787-1794. doi:10.1007/s12665-011-0981-4

Cheng JD, Huang YC, Wu HL, Yeh JL, Chang CH (2005) Hydrometeorological and land use attributes of debris flows and debris floods during typhoon Toraji, July 29-30, 2001 in central Taiwan. J Hydrol 306:161-173. doi:10.1016/ j.jhydrol.2004.09.007

Chien-Yuan C, Tien-Chien C, Fan-Chieh Y, Wen-Hui Y, Chun-Chieh T (2005) Rainfall duration and debris-flow initiated studies for real-time monitoring. Environ Geol 47:715-724. doi:10.1007/s00254-004-1203-0

Chuang SC, Chen H, Lin GW, Lin CW, Chang CP (2009) Increase in basin sediment yield from landslides in storms following major seismic disturbance. Eng Geol 103:59-65. doi:10.1016/j.enggeo.2008.08.001

Claessens L, Knapen A, Kitutu MG, Poesen J, Deckers JA (2007) Modelling landslide hazard, soil redistribution and sediment yield of landslides on the
Ugandan footslopes of Mount Elgon. Geomorphology 90:23-35. doi:10.1016/j.geomorph.2007.01.007

Coe J, Kinner D, Godt J (2008) Initiation conditions for debris flows generated by runoff at Chalk Cliffs, central Colorado. Geomorphology 96:270-297. doi:10.1016/j.geomorph.2007.03.017

Crosta G (1998) Regionalization of rainfall thresholds: an aid to landslide hazard evaluation. Environ Geol 35:131-145. doi:10.1007/s002540050300

Crozier MJ (1999) Prediction of rainfall-triggered landslides: a test of the antecedent water status model. Earth Surf Proc Land 24:825-833. doi:10.1002/(SICI)1096-9837(199908)24:9<825::AID-ESP14>3.3.CO;2-D

Dadson SJ, Hovius N, Chen H, Dade WB, Hsieh ML, Willett SD et al (2003) Links between erosion, runoff variability and seismicity in the Taiwan orogeny. Nature 426:648-651. doi:10.1038/nature02150

Dadson SJ, Hovius N, Chen H, Dade WB, Lin JC, Hsu ML et al (2004) Earthquaketriggered increase in sediment delivery from an active mountain belt. Geology 32:733-736. doi:10.1130/G20639.1

Dahal R, Hasegawa S (2008) Representative rainfall thresholds for landslides in the Nepal Himalaya. Geomorphology 100:429-443. doi:10.1016/j.geomorph.2008.01.014

Dai FC, Lee CF, Ngai YY (2002) Landslide risk assessment and management and management: an overview. Eng Geol 64:65-87. doi:10.1016/S0013-7952(01)00093-X

Dou J, Oguchi T, Hayakawa YS, Uchiyama S, Saito H, Paudel U (2014) GIS-based landslide susceptibility mapping using a certainty factor model and its validation in the Chuetsu area, central Japan. Landslide Science for a Safer Geoenvironment, Springer International Publishing:419-424. doi:10.1007/978-3-319-05050-8_65

Glade T (1997) The temporal and spatial occurrence of rainstorm-triggered landslide events in New Zealand. Victoria University of Wellington, Dissertation

Glade T, Crozier M, Smith P (2000) Applying probability determination to refine landslide-triggering rainfall thresholds using an empirical "antecedent daily rainfall model". Pure Appl Geophys 157:1059-1079. doi:10.1007/s000240050017

Guzzetti F, Carrara A, Cardinali M, Reichenbach P (1999) Landslide hazard evaluation: a review of current techniques and their application in a multi-scale study, central Italy. Geomorphology 31:181-216. doi:10.1016/ S0169-555X(99)00078-1

Guzzetti F, Peruccacci S, Rossi M, Stark C (2007) Rainfall thresholds for the initiation of landslides in central and southern Europe. Meteorol Atmos Phys 98:239-267. doi:10.1007/s00703-007-0262-7

Guzzetti F, Peruccacci S, Rossi M, Stark C (2008) The rainfall intensity-duration control of shallow landslides and debris flows: an update. Landslides 5:3-17. doi:10.1007/s10346-007-0112-1

Ho CS (1986) A synthesis of the geologic evolution of Taiwan. Tectonophysics 125:1-16. doi:10.1016/0040-1951(86)90004-1

Ho CS (1988) An introduction to the geology of Taiwan, explanatory text of the geologic map of Taiwan. Central Geological Survey, the Ministry of Economic Affairs, Taipei, Taiwan

Hong Y, Hiura H, Shino K, Sassa K, Suemine A, Fukuoka H et al (2005) The influence of intense rainfall on the activity of large-scale crystalline schist landslides in Shikoku Island, Japan. Landslides 2:97-105. doi:10.1007/s10346004-0043-Z

Hovius N, Stark CP, Allen PA (1997) Sediment flux from a mountain belt derived by landslide mapping. Geology 25:231-234. doi:10.1130/00917613(1997)025<0231:SFFAMB >2.3.CO;2

Iverson RM, Reid ME, LaHusen RG (1997) Debris-flow mobilization from landslides. Annu Rev Earth PI Sc 25:85-138. doi:10.1146/annurev.earth.25.1.85

Jakob M (2006) Hydrometeorological thresholds for landslide initiation and forest operation shutdowns on the north coast of British Columbia. Landslides 3:228-238. doi:10.1007/s10346-006-0044-1

Jakob M, Weatherly H (2003) A hydroclimatic threshold for landslide initiation on the North Shore Mountains of Vancouver, British Columbia. Geomorphology 54:137-156. doi:10.1016/S0169-555X(02)00339-2

Jan CD, Chen CL (2005) Debris flows caused by typhoon Herb in Taiwan. In: Jakob M, Hungr O (eds) Debris flow hazards and related phenomena. Springer, Berlin Heidelberg, pp 539-563. doi:10.1007/3-540-27129-5_21

Jibson R (1989) Debris flow in southern Puerto Rico. Geological Society of America, Special Paper, vol 236:29-55. doi:10.1130/SPE236-p29

Keefer D, Wilson R, Mark R, Brabb E, Brown W, Ellen S et al (1987) Real-time landslide warning during heavy rainfall. Science 238:921-925. doi:10.1126/ science.238.4829.921

Kim SK, Hong WP, Kim YM (1992) Prediction of rainfall-triggered landslides in Korea. In: Bell DH (ed) Landslides, Proceedings of the Sixth International Symposium on Landslides, Christchurch, 10-14 February 1992, vol 2. Balkema, Rotterdam, pp 989-994 
Kirschbaum D, Adler R, Adler D, Peters-Lidard C, Huffman G (2012) Global distribution of extreme precipitation and high-impact landslides in 2010 relative to previous years. J Hydrometeorol 13:1536-1551. doi:10.1175/JHM-D-12-02.1

Korup O, Gorum T, Hayakawa Y (2012) Without power? Landslide inventories in the face of climate change. Earth Surf Proc Land 37:92-99. doi:10.1002/esp.2248

Larsen M, Simon A (1993) A rainfall intensity-duration threshold for landslides in a humid-tropical environment: Puerto Rico. Geogr Ann A 75:13-23. doi:10.2307/521049

Li YH (1976) Denudation of Taiwan island since the Pliocene epoch. Geology 4:105-107. doi:10.1130/0091-7613(1976)4<105:DOTIST>2.0.CO;2

Lin CW, Shieh CL, Yuan BD, Shieh YC, Liu SH, Lee SY (2003) Impact of Chi-Chi earthquake on the occurrence of landslides and debris flows: example from the Chenyulan River watershed, Nantou, Taiwan. Eng Geol 71:49-61. doi:10.1016/S0013-7952(03)00125-X

Lin GW, Chen H (2012) The relationship of rainfall energy with landslides and sediment delivery. Eng Geol 125:108-118. doi:10.1016/j.enggeo.2011.11.010

Omura H (1980) Fundamental study on forecasting of landslide area (I) - relation between total precipitation, resistance index and landslide area ratio -. Journal of the Japan Society of Erosion Control Engineering 33:15-25 (in Japanese with English abstract). doi:10.11475/sabo1973.33.2_15

Omura H (1982) Forecast method of landslide area ratio by gamma distribution model. Journal of the Japan Society of Erosion Control Engineering 35:31-37 (in Japanese with English abstract). doi:10.11475/sabo1973.35.3

Onodera T, Yoshinaka R, Kazama H (1974) Slope failures caused by heavy rainfall in Japan. Proc. 2nd Int. Congress of the Int Ass Eng Geol, v. 11. San Paulo 11:1-10. doi:10.5110/jjseg.15.191

Petley D (2012) Global patterns of loss of life from landslides. Geology 40:927-930. doi:10.1130/G33217.1

Saito H, Nakayama D, Matsuyama H (2010a) Relationship between the initiation of a shallow landslide and rainfall intensity-duration thresholds in Japan. Geomorphology 118:167-175. doi:10.1016/j.geomorph.2009.12.016

Saito H, Nakayama D, Matsuyama H (2010b) Two types of rainfall conditions associated with shallow landslide initiation in Japan as revealed by normalized soil water index. SOLA 6:57-60. doi:10.2151/sola.2010-015

Saito H, Matsuyama H (2012) Catastrophic landslide disasters triggered by record-breaking rainfall in Japan: their accurate detection with normalized soil water index. SOLA 8:81-84. doi:10.2151/sola.2012-021

Saito H, Korup O, Uchida T, Hayashi S, Oguchi T (2014) Rainfall conditions, typhoon frequency, and contemporary landslide erosion in Japan. Geology 42:999-1002. doi:10.1130/G35680.1

Shieh CL, Chen YS, Tsai YJ, Wu JH (2009) Variability in rainfall threshold for debris flow after the Chi-Chi earthquake in central Taiwan, China. Int I Sed Res 24:177-188. doi:10.1016/S1001-6279(09)60025-1

Shieh SL (2000) User's Guide for Typhoon Forecasting in the Taiwan Area (VIII). Central Weather Bureau, Taipei

Teng LS (1990) Geotectonic evolution of late Cenozoic arc-continent collision in Taiwan. Tectonophysics 183:57-76. doi:10.1016/0040-1951(90)90188-E

Terlien MT (1998) The determination of statistical and deterministic hydrological landslide-triggering thresholds. Environ Geol 35:124-130. doi:10.1007/ s002540050299

Wang B, Ho L (2002) Rainy season of the Asian-Pacific summer monsoon. J Climate 15:386-398. doi:10.1175/1520-0442(2002)015<0386:RSOTAP > 2.0.CO;2

Wieczorek G, Glade T (2005) Climatic factors influencing occurrence of debris flows. In: Jakob M, Hunger O (eds) Debris-flow Hazards and Related Phenomena. Springer, Berlin, pp 325-362. doi:10.1007/3-540-27129-5_14

Willett SD, Fisher D, Fuller C, Yeh EC, Lu CY (2003) Erosion rates and orogenic wedge kinematics in Taiwan inferred from apatite fission track thermochronometry. Geology 31:945-948. doi:10.1130/G19702.1

Wu CC, Kuo YH (1999) Typhoons affecting Taiwan: current understanding and future challenges. B Am Meteorol Soc 80:67-80. doi:10.1175/15200477(1999)080<0067:TATCUA>2.0.CO;2

Wu CH, Chen SC (2009) Determining landslide susceptibility in central Taiwan from rainfall and six site factors using the analytical hierarchy process method. Geomorphology 112:190-204. doi:10.1016/j.geomorph.2009.06.002

Yu SB, Chen HY, Kuo LC (1997) Velocity field of GPS stations in the Taiwan area. Tectonophysics 274:41-59. doi:10.1016/S0040-1951(96)00297-1

\section{Submit your manuscript to a SpringerOpen ${ }^{\odot}$ journal and benefit from:}

- Convenient online submission

- Rigorous peer review

- Immediate publication on acceptance

- Open access: articles freely available online

- High visibility within the field

- Retaining the copyright to your article

Submit your next manuscript at $>$ springeropen.com 